\title{
GENETIC AND PHENOTYPIC TRENDS OF 305-DAY MILK YIELD OF HOLSTEIN COWS RAISED AT COMMERCIAL FARM IN EGYPT
}

\author{
S. Abou-Bakr
}

Animal Production Department, Faculty of Agriculture, Cairo University, Giza, Egypt

\section{SUMMARY}

The purpose of this study was to estimate the genetic and phenotypic trends of 305- day milk yield of Holstein cows in a commercial farm. Data consisted of 2654 lactation records for 850 Holstein cows sired by 316 sires, collected from 1991 to 2007. The data were analyzed using Least Squares technique to examine the effect of year, season of calving, parity and interaction between season of calving and parity factors on 305- day milk yield. Heritability of 305 day milk yield trait and breeding values were estimated using VCE 6.0.2 software.

Highly significant effects for year of calving, parity and the interaction between season of calving and parity on the 305- day milk yield were observed. However, season of calving had a non significant effect on the 305-day milk yield. The average of 305- day milk yield was $7042 \mathrm{~kg}$. The heritability estimate of 305- day milk yield was 0.06. The regression of 305-day milk yield on year of calving showed a significant negative phenotypic trend being $-91.6 \mathrm{~kg}$ per year. However, the genetic trend depicted a significant positive trend (+ $2.19 \mathrm{~kg}$ per year). In conclusion, although the trend in the estimated breeding values found for cows was positive, it still did not lead to change in the average milk production due to the probable reduction in the nutritional and /or management conditions of the herd.

Keywords: Heritability, genetic and phenotypic trends, 305- day milk yield, Holstein cows

\section{INTRODUCTION}

The increase of production efficiency could be achieved either by improving the environmental conditions of the population, by improving the mean breeding values of members of the population, or by a combination of both (Katkasame et al., 1996). Fundamental aims of animal breeding schemes are to increase profits of keeping producing animals. Partitioning the phenotypic value of the most important economic important into genetic and environmental component plays an important role in determining and estimating the real progress that can be achieved. Genetic trend is defined as a change in performance per unit of time due to change in the mean breeding value while phenotypic trend is a change in production per unit of time (Herbert and Bhatnagar, 1988).

Issued by The Egyptian Society of Animal Production 
The estimates of trends in the performance traits of dairy cattle seem to vary from breed to breed and from herd to herd due to differences in locality, management and selection objectives (Amimo et al., 2007). The trends are indicative of the progress or decline that has been attained using the breeding strategy in place (Rege and Mosi, 1989; Njubi et al., 1992 and Ojango and Pollot, 2001).

The measurement of genetic capacity of the dairy cows is of economic importance and improvement in genetic capacity is measured by the genetic trend (Kunaka and Makuza, 2005). Due to economic value of milk, milk yield has traditionally been the single most important trait of dairy cattle selection programs in most countries (Campos et el., 1994). Therefore, milk yield is expected to show positive (favorable) genetic trend (Rege, 1991). In general, favorable phenotypic and genetic trends can be achieved if the environment and breeding management are improved. There is, therefore, a need to continuously evaluate the genetic and phenotypic parameters and trends in dairy cattle, to monitor whether the parameters and trends are desirable for each trait (Amimo et al., 2007).

The purpose of this study was to estimate the genetic and phenotypic trends of 305- day milk yield of Holstein cows reared in a commercial farm.

\section{MATERIALS AND METHODS}

A total of 2654 lactation records for 850 Holstein cows sired by 316 sires were used in the present study. Data were collected from a commercial farm (International Company for Animal Wealth), located at Giza Governorate in Egypt. The data were obtained during the period from 1991 to 2007. The original herd was imported from the USA as 425 pregnant heifers in 1991. Cows are artificially inseminated at the third observed estrus after parturition using frozen semen imported from USA and Canada. All cows were machine milked.

The 305- day milk yield is calculated according to the following equation: $305-$ day milk yield $=($ total milk yield / (lactation period +100$)) * 405($ ICAR, 2000) . Lactations longer than 130 days were included in the analysis.

\section{Statistical analysis:}

The data were analyzed using Least Squares technique (XLSTAT, 2009) to examine the effect of year, season of calving, parity and interaction between season of calving and parity factors, as fixed effects, on 305- day milk yield. Preliminary analysis of data indicated that the interactions between each of years and season of calving and between year of calving and parity could not be calculated due to missed cells of data. The following statistical model was used:

Where,

$$
\mathrm{Y}_{\mathrm{ijkl}}=\mu+\mathrm{YC}_{\mathrm{i}}+\mathrm{SC}_{\mathrm{j}}+\mathrm{IP}_{\mathrm{k}}+(\mathrm{SC} * \mathrm{IP})_{\mathrm{jk}}+\mathrm{e}_{\mathrm{ijk}}, \quad \text { (A) }
$$

$\mathrm{Y}_{\mathrm{ijk} \mathrm{l}}=$ 305- day milk yield,

$\mu=$ the overall mean,

$\mathrm{YC}_{\mathrm{i}}=$ the fixed effect of the $\mathrm{i}^{\text {th }}$ year of calving $(\mathrm{i}=1991,1992, \ldots, 2007)$,

$\mathrm{SC}_{\mathrm{j}}=$ the fixed effect of the $\mathrm{j}^{\text {th }}$ season of calving $(\mathrm{j}=1,2,3,4)$, where $1=$ winter (December, January, February), 2= spring (March, April, May), 3= summer (June, July, August) and 4= autumn (September, October, November).

$\mathrm{IP}_{\mathrm{k}}=$ the fixed effect of the $\mathrm{k}^{\text {th }}$ parity $(\mathrm{k}=1,2, \ldots, 7)$,

$\left(\mathrm{SC}^{*} \mathrm{IP}\right)_{\mathrm{jk}}=$ the interaction between season of calving and parity, and 
$\mathrm{e}_{\mathrm{ijkl}}=$ random error assumed NID $\left(0, \sigma^{2} \mathrm{e}\right)$.

The heritability and breeding values were estimated by using VCE 6.0.2 software (Groeneveld et al., 2008) according to the following statistical model:

$\mathrm{Y}_{\mathrm{ijk} l m n}=\mu+\mathrm{A}_{\mathrm{i}}+\mathrm{Per}_{\mathrm{j}}+\mathrm{YC}_{\mathrm{k}}+\mathrm{SC}_{\mathrm{l}}+\mathrm{IP}_{\mathrm{m}}+(\mathrm{SC} * \mathrm{IP})_{1 \mathrm{~m}}+\mathrm{e}_{\mathrm{ijk}} \mathrm{i}_{\mathrm{lmn}},(\mathrm{B})$

Where,

$\mathrm{A}_{\mathrm{i}}=$ the random effect of animal additive genetic effect, $\mathrm{A}_{\mathrm{i}} \sim \mathrm{NID}\left(0, \sigma_{\mathrm{A}}^{2}\right)$,

$\mathrm{Per}_{\mathrm{j}}=$ the random permanent environment effect on the animal, $\operatorname{Per}_{\mathrm{j}} \sim \mathrm{NID}\left(0, \sigma_{\mathrm{per}}^{2}\right)$, and the other components of the model was defined in the model (A).

Phenotypic trend was estimated by regression of the 305- day milk yield on the year of calving. The genetic trend was obtained by regression of the breeding value for animal on the year of calving.

\section{RESULTS AND DISCUSSION}

Preliminary least-squares analysis showed highly significant effects for year of calving and parity and the interaction between season of calving and parity on the 305 day milk yield as presented in Table 1. However, season of calving had a nonsignificant effect on the 305- day milk yield. Abdelharith, (2008) reported nonsignificant effect of season of calving on 305- day milk yield. Year of calving had a significant effect $(\mathrm{P}<0.0001)$ on the 305-day milk yield, this was consistent with reports in the literature (Rege and Mosi, 1989; Olukoye and Mosi, 2002 and Amimo et al., 2007). Parity significantly $(\mathrm{P}<0.0001)$ influenced 305 - day milk yield, this result is similar to findings in other studies (Rege, 1991; Njubi et al., 1992; Olukoye and Mosi, 2002 and Abdelharith, 2008).

Table 1. Mean-Squares of 305-day milk yield of Holstein cows

\begin{tabular}{lcc}
\hline Source of variation & df & Mean Square \\
\hline Year of calving & 16 & $39056056^{* *}$ \\
Season of calving & 3 & $2311538^{\mathrm{NS}}$ \\
Parity & 6 & $13557716^{* *}$ \\
Season * Parity & 18 & $4809074^{* *}$ \\
Error & 2610 & 2367728 \\
\hline$* * \mathrm{P}<0.0001 \quad \mathrm{NS}=$ Not Significant $(\mathrm{P}>0.05)$ &
\end{tabular}

The average of 305 day- milk yield was $7042 \mathrm{~kg}$. This estimate was higher than that found by Bakir and Kaygisiz, 2004; Atil and Khattab, 2005; Amimo et al., 2007 and Abdelharith, 2008.

Phenotypic fluctuations in the 305- day milk yield were noticed (Fig. 1) in the present study. There was a significant $(\mathrm{P}<0.02)$ negative phenotypic trend in milk yield with an overall rate of $-91.6 \pm 35.16 \mathrm{~kg}$ per year. The decline in this trait may largely be attributed to environmental factors. The variation in milk yield from one year to another could be attributed to changes in age of the animals, attacks of different diseases and management practices level followed from year to another, e.g. fluctuations in feed availability, and quality and prices. Rege (1991); Atil et al., (2001); Kunaka and Makuza (2005) and Amimo et al. (2007) also came to the same conclusion. 


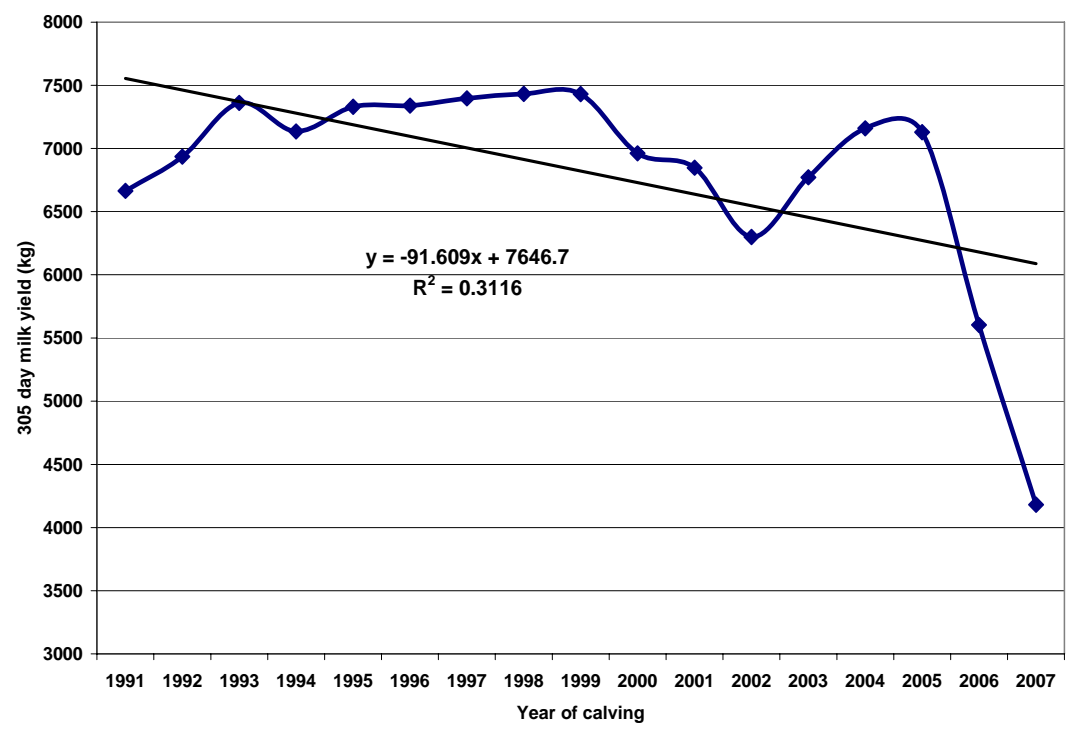

Figure 1. Phenotypic trend for the 305- day milk yield

The heritability estimate of 305- day milk yield and its standard error was $0.06 \pm$ 0.04. This estimate was less than estimates found in the literature (Jamrozik and Schaeffer (1997; 0.32); Dematawewa and Berger (1998; 0.20); Abou-Bakr et al. (2000; 0.09); Ojango and Pollott (2001; 0.29); Abou-bakr (2003; 0.08); Kaya et al. (2003; 0.25); Atil and Khattab (2005; 0.26) and Abdelharith (2008; 0.19)). The low heritability estimate for 305- day milk yield revealed in this study could be attributed to the use of genetically similar sires from the same source over a long period. Differences in heritability estimates among various studies for the same trait of the same breed may be due to differences in the record number used, the correction for different non-genetic factors, the model used and the methodology for estimating heritability of the trait.

The estimated breeding values of Holstein cows for 305-day milk yield ranged from $-32.780 \mathrm{~kg}$ to $+47.994 \mathrm{~kg}$ (Table 2 ). The genetic trend for 305 - day milk yield depicted a significant positive $(+2.196 \pm 0.93 \mathrm{Kg}, \mathrm{P}=0.033)$ value (Figure 2$)$. These results indicate a slight genetic improvement in the present herd overtime. It might be due to the use of imported semen from sires having some better higher breeding values for milk yield.

The positive genetic trend obtained in the present study was also found by Ojango and Pollott $(2001 ;+12.9 \mathrm{~kg})$; Atil and Khattab $(2005 ;+44.85 \mathrm{~kg})$; Kunaka and Makuza (2005; +14.4 kg); Peixoto et al.,(2006; +7.09 kg) and Abdelharith (2008; $+0.27 \mathrm{~kg}$ ). Amimo et al. (2007) reported that genetic trend for 305-day milk yield was negative $(-2.1 \mathrm{~kg} /$ year $)$. 
Table 2. Estimates of breeding values

\begin{tabular}{cc}
\hline Year of calving & Breeding value(kg) \\
\hline 1991 & +1.008 \\
1992 & -8.593 \\
1993 & -6.711 \\
1994 & +2.317 \\
1995 & +21.829 \\
1996 & +20.044 \\
1997 & +17.167 \\
1998 & +5.566 \\
1999 & -25.304 \\
2000 & -32.780 \\
2001 & +20.251 \\
2002 & -2.106 \\
2003 & +24.924 \\
2004 & +13.522 \\
2005 & +35.619 \\
2006 & +33.748 \\
2007 & +47.994 \\
\hline
\end{tabular}

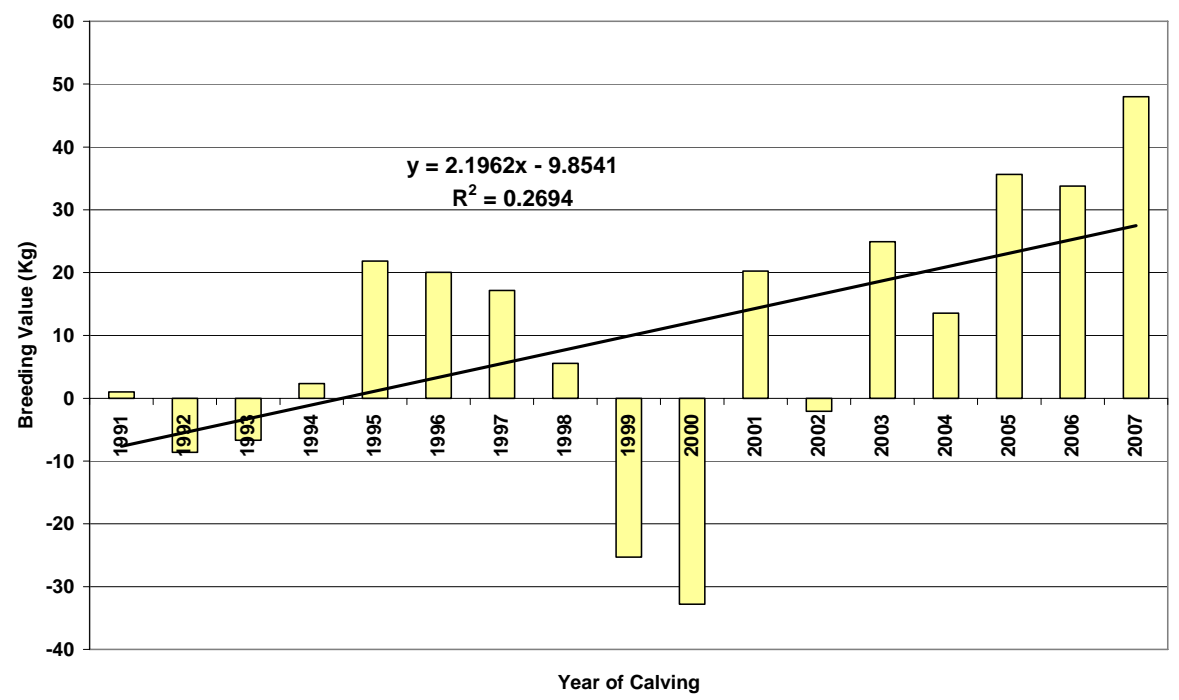

Figure 2. Genetic trend for the 305- day milk yield 


\section{CONCLUSION}

Although the trend in the estimated breeding values found for cows of the present study was positive, it still did not lead to a positive change the average milk production. This result could be explained by the probable reduction in the nutritional and / or management conditions of the herd.

\section{REFERENCES}

Abdelharith, Hanaa, 2008. Genetic and phenotypic trends of milk yield and reproductive traits for Friesian herd raised in Mid-Delta. Egypt. J. Appl. Sci., 23(8A):1-14.

Abou-Bakr, S., U.M.EL-Saied and M.A.M. Ibrahim, 2000. Genetic and phenotypic parameters for milk yield, days open and number of services per conception of Holstein cows of a commercial herd in Egypt. Egyptian J. Anim. Prod., 37(1):917.

Abou-Bakr, S., 2003. Estimates of heritability and breeding values using single test day records of first lactation milk yield of Holstein cows. Egyptian J. Anim. Prod., 40(2):121-128.

Amimo, J.O., J.W., Wakhungu, B.O., Inyangala, and R.O. Mosi, 2007. The effects of non-genetic factors and estimation of genetic and phenotypic parameters and trends for milk yield in Ayrshire cattle in Kenya. Livestock Res. Rural Development, 19(1):1-9. http://www.cipav.org.co/Irrd19/1/amim19013.htm.

Atil, H., A.S., Khattab, and C., Yakupoglu, 2001. Genetic analysis for milk traits in different herds of Holstein Friesian cattle in Turkey. J. Biological Sci., 1(8):737741.

Atil, H. and A.S., Khattab, 2005. Estimates of genetic trends for productive and reproductive traits of Holstein Friesian cows in Turkey. Pakistan J. Biological Sci., 8(2); 202-205.

Bakir,G. and A. Kaygisiz , 2004. Estimates of trends components of 305 days milk yield at Holstein Cattle's. J. Biological Sciences, 4(4): 486-488.

Campos, M.S., C.J. Wilcox, C.M. Becerril and A. Diz, 1994. Genetic parameters for yield and reproductive traits of Holstein and Jersey cattle in Florida. J. Dairy Sci., 77: 867-873.

Dematawewa, C.M. and P.J. Berger, 1998. Genetic and phenotypic parameters for 305-day yield, fertility and survival in Holsteins. J. Dairy Sci., 81: 2700-2709.

Groeneveld, E., M. Kovac and N. Mielenz, 2008. VCE 6.0.2, Co-variance components estimation package, Institute of Farm Animal Genetics, Mariensee, Germany.

Herbert, S. and D.S. Bhatnagar, 1988. Genetic trends of economic traits in dairy cattle. A review. Agril. Rev., 9:200-216.

ICAR, 2000. Yearly enquiry on the situation and results of cow milk recording in member countries.

Jamrozik, J. and L.R. Schaeffer, 1997. Estimates of genetic parameters for a test day model with random regressions for yield traits of first lactation Holstein. J. Dairy Sci., 80: 762-770. 
Katkasame, S., S. Tumwasorn, B. Thaninndratarn and S. Pasanpanich, 1996. Trend analysis on milk production traits in the dairy farming promotion organization of Thailand. Kasetsart J. (Nat. Sci.) 30: 211-219.

Kaya, I., Y.Akbas and C.U. Zmay, 2003. Estimation of breeding values for dairy cattle using test-day milk yield. Turk.J.Vet. Anim.Sci., 27:459-464.

Kunaka, K. and S. M. Makuza, 2005. Genetic and environmental trends for milk traits in the Zimbabwean Holstein-Friesian Population. Pakistan J. Biological Sci., 8(7): 1011-1015.

Njubi, D.M., J.E.O. Rege, W. Thorne, E. Collins-Lusweti and R. Nyambaka, 1992. Genetic and environmental variation in reproductive and lactational performance of Jersey cattle in the coastal lowland semi-humid tropics. Tropical Animal Health and Production, 24(4): 231-241.

Ojango, J.M. and G.E. Pollott, 2001. Genetic of milk yield and fertility traits in Holstein-Friesian cattle on large-scale Kenyan farms. J. Anim. Sci., 79:17421750.

Olukoye, G.A. and R.O. Mosi, 2002. Non-genetic causes of heterogeneity of variance in milk yield among Holstein Friesian herds in Kenya. The Kenya Vet., 25: 1823.

Peixoto, M.G.C.D., R.S. Verneque, R.L. Teodoro, V.M. Penna and M.L. Martinez, 2006. Genetic trend for milk yield in Guzerat herds participating in progeny testing and MOET nucleus schemes. Genet. Mol. Res., 5(3):454-465.

Rege, J.E.O., 1991. Genetic analysis of reproductive and productive performance of Friesian cattle in Kenya. J. Anim. Breed. and Genet., 108: 412-432.

Rege, J.E.O. and R.O. Mosi , 1989. Analysis of the Kenyan Friesian breed from 1968 to 1984: genetic and environmental trends and related parameters of milk production. Bulletin of Animal Health Production in Africa, 37: 267.

XLSTAT,2009. Statistical software for MS Excel- Statistics and data analysis with MS. 
الإتجاهات الوراثية و المظهرية لصفة انتاج اللبن فى 305 يوم فى قطيع هولثتين بمزرعة

تجارية فى مصر.

سامى أبو بكر

قسم الإتتاج الحيوانس، كلية الزراعة، جامعة القاهرة، الجبزة،مصر

الهدف من الدراسة هو تقدير الإتجاهات الوراثية و المظهرية لصفة انتاج اللبن فى 305 يوم لأبقار

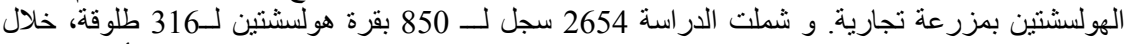

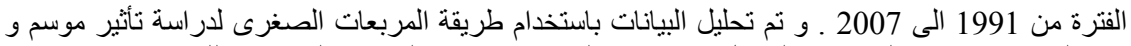

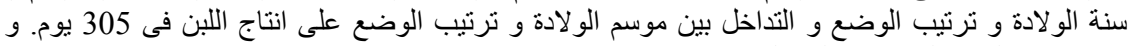

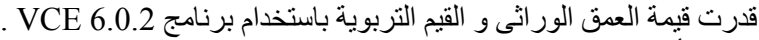

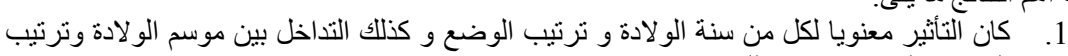

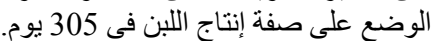

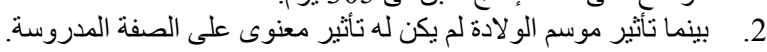
3.

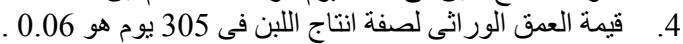

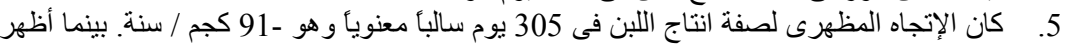

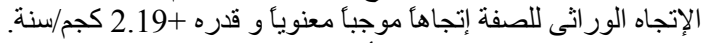

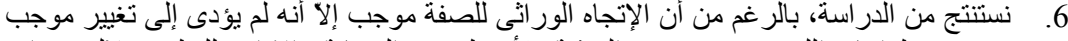

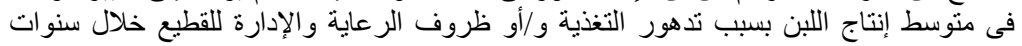

